\title{
Nephroprotective Effect and Unani Medicine: A Review
}

\author{
Md. Anzar Alam ${ }^{1 *}$, MA Quamri' ${ }^{1}$ MA Siddiqui ${ }^{1}$, Ubaidul $\mathrm{Hai}^{2}$ and G. Sofi ${ }^{3}$
}

${ }^{1}$ Department of Moalajat (Medicine) NIUM, Bangalore, India

${ }^{2}$ Department of IImul Saidla, NIUM, Bangalore, India

${ }^{3}$ Department of IImul Advia, NIUM, Bangalore, India

\begin{abstract}
Kidneys are one of the vital organs of body which carry out several important roles in regulating the normal body functions. Its major role is formation of Baul (urine) and execute water and salt balance, and release of hormone. Excess use of antibiotics (chiefly aminoglycosides), NSAIDS and anti-tubercular drugs damage the kidneys. Renal failure is the condition where withholding of metabolic products in response to weakening of function. In recent time its management is by dialysis, kidney transplantation or chemotherapy. This type of treatment is costly and not affordable by everyone. For this solution there are many drugs describe in Unani literature from Mawalide Salasa origin like; plant, mineral and animals that have negligible side effects and easily available their native. The present review attempted to clarify the role of the drug repertoire of the Unani Medicine which are used for the management of amraze kuliya/zofe kuliya scientifically proved useful in treating renal disorders
\end{abstract}

Keywords: Nephroprotective; Unani medicine; Mawalide salasa

\section{Introduction}

At present nephrotoxicity (Greek: nephros means kidney and toxicity means the state of poisonous) is one of the most familiar kidney problems and occurs when body is exposed to a harmful drugs or toxins and person suffered to diabetic or hypertension [1]. When kidney damage body incapable to rid of excess urine and wastes from the body and blood electrolytes such as (potassium and magnesium), will be all become high [2]. There are many healing agents like aminoglycoside antibiotics, NSAID's, chemotherapeutic and antitubercular drugs can badly affect the kidney leads to acute renal failure, chronic interstitial nephritis and nephritic syndrome [3]. Prevalence of chronic kidney disease in India is 7852 per million [4]. Prevalence of renal failure in worldwide is estimated $8-16 \%$ in 2013 [5]. In India the dialysis population is growing at the rate of $10-20 \%$ annually [6]. Chronic kidney disease is the main cause of death and hammering of disability-adjusted life-years worldwide, but wakefulness is low among patients and health-care contributor [7]. More than $80 \%$ of the patients of kidney problem receiving treatment for end-stage kidney problem are approximate to be in wealthy countries with huge elderly populations and worldwide access to health care [8]. Population of India is 1.1 billion and it is growing. Per capita annual income is about $\$ 530$ and about $30 \%$ population lives on less than $\$ 110$ per year. It costs anywhere between $\$ 4,440$ and $\$ 8,880$ per year for any kind of renal replacement therapy, and this is obviously unaffordable for the vast majority of people in India [4]. According to WHO, over $80 \%$ of the world population relies on traditional medicine for their primary health care need. However the traditional medical practices are pragmatic in nature, over 200 million people in India with restricted access to the planned health canters depends on varying degrees in the traditional system of medicine to fulfil their health care needs [9]

Drugs from Unani Medicine are usually used in treating or preventing ailments or diseases, and it is considered to play a valuable role in health care. Therefore, the study of plants/minerals and animal as a source of medicine has become more significant in the circumstance of present global trade picture where oxidative stress is found to be one of the main causes of health hazards [10]. It is reported that 61 plant families (most dominant family being Euphorbiaceae), 143 species, $85 \%$ medicinal plant used for diuretic purpose, $10 \%$ used in burning urination and $6.3 \%$ against stone formation and leaves $30 \%$, root $22 \%$ , seed $18 \%$, fruit $15 \%$ pod $10 \%$,bark $8 \%$, gum $5 \%$ and whole plant $2 \%$ have beneficial effect in renal diseases [11]. It was intangible that such indigenous plants would be useful, at least as rejuvenator for the cure of different kind of degenerative kidney disease [12].

Many plants have been used for the management of kidney problem in conventional system of medicine all over the world. Conventional knowledge will provide as a powerful search engine and most significantly, will greatly make easy, deliberate, focused and safe natural products investigation to retrieve the drug discovery method [13]. Developing a reasonable herbal treatment to treat renal disorders require systematic investigation of domains like acute renal failure, nephritic syndrome and chronic interstitial nephritis [14]. According to nature of origin and frequently used, drugs are classified as three categorized (Figure 1). Medicinal plants have different part that has different active constituents, but it is reported that leaves and flavonoids possessing parts have more nephroprotective activity in comparison to other parts and other active constituents. It is illustrated in (Figures 2-4) [11].

Unani Medicines possesses healing property due to the presence of their active components. There are different types of treatment method described in classical text of Unani literature under the heading of amraze kuliya wa masana Such as, regimenal therapy (Nutool, Hammam Yabis, Tareeq, Huqna, Fasd, Qai, Idrar Baul, Takmeed, Aabzan and Dalk), Diet therapy and Drug therapy including- Minerals, Plants and Animal Origin Drugs used as single plant part or in compound formulation [15-17].

Single drugs which performs nephroprotective activity are claimed to have actions of Mudirr-e-Baul (Diuretic), Mufattit-e-Hasat (Lithotriptic), Kasir-e- Riyah (Carminative); Taqwiyat-e-Gurda (Renal tonic) are described by Zakaria Rhazi in Al-Havi Fit Tibb $10^{\text {th }}$ Volume

*Corresponding author: Md. Anzar Alam, PG Scholar (MD), Department of Moalajat (Medicine) National Institute of Unani Medicine (NIUM), (An Autonomous Organization under Ministry of AYUSH, Govt. of India, Bangalore-560091, India, Tel: +91-9902146030; E-mail: dranzarnium@gmail.com

Received: April 24, 2015; Accepted: February 17, 2016; Published: February 24,2016

Citation: Md Alam A, Quamri MA, Siddiqui MA, Hai U, Sofi G (2016) Nephroprotective Effect and Unani Medicine: A Review. J Nephrol Ther 6: 236 doi:10.4172/2161-0959.1000236

Copyright: ( $) 2016$ Md Alam A, et al. This is an open-access article distributed under the terms of the Creative Commons Attribution License, which permits unrestricted use, distribution, and reproduction in any medium, provided the original author and source are credited. 


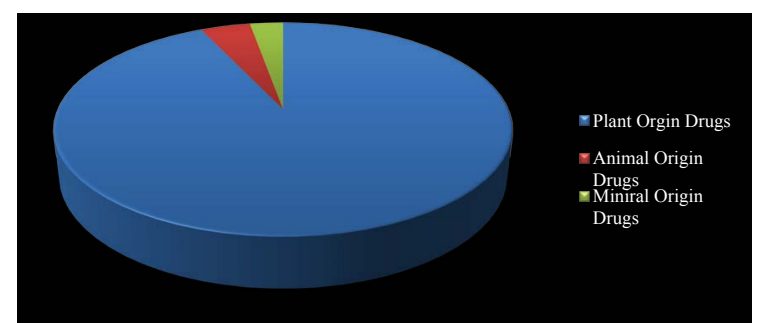

Figure 1: Distribution of drugs according to the origin

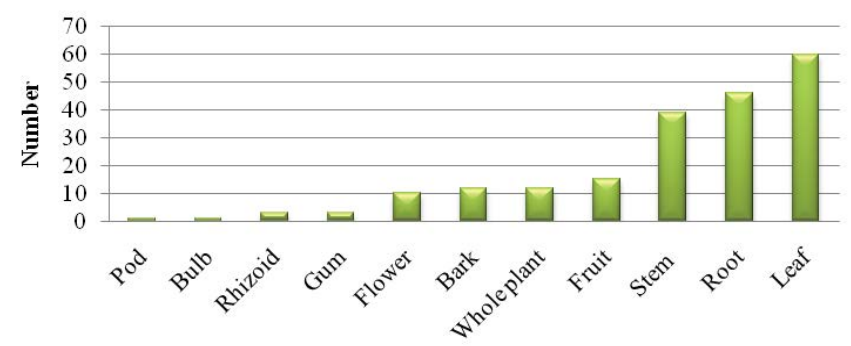

Plant Parts

Figure 2: Distribution of plant part used in kidney protection.

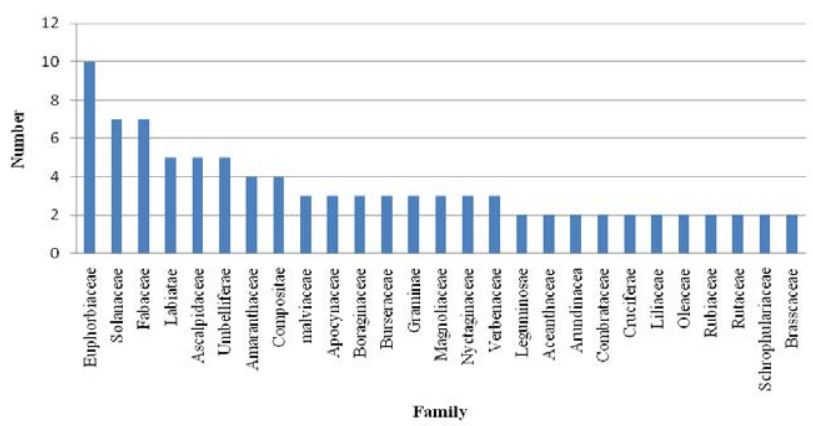

Figure 3: Family wise distribution of plants used in kidney protection.

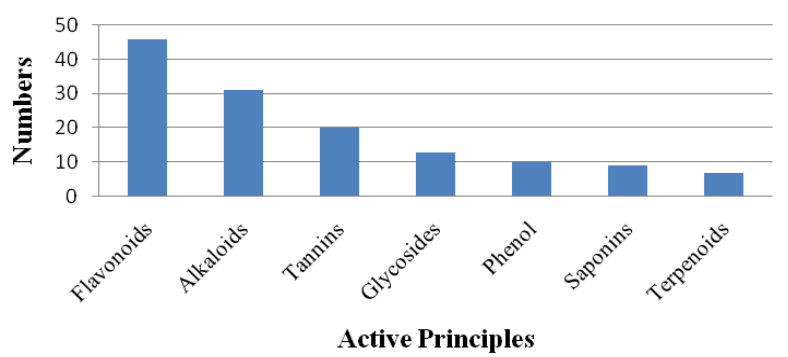

Figure 4: Distribution of active principles used in kidney protection.

such as; Kabab Chini (Pipeber cubeba), Gule Surkh (Rosa damascena), Kasni (Chicorium intybus), (Darchini (Cinamo zeylanicum), Kundur (Boswellia serrata), Turanjabin (Alhagi maurorum), Khar-e-Khasak (Tribulus terrestris), Kanduri (Coccinia indica), Tukhm-e-Gazar (Daucus carota), Tukhm-e-Karafs (Apium graveolans), Tukhme-aspand (Peganum harmala), Nankhwah (Ptychotis ajowan), Baadiyan (Foeniculum vulgare), Maghz-e-Tukhm-e-Kharbooza (Cucumis melo), Maghz-e-Tukhm-e-Khiyarain (Cucumis sativa), Post-e-Bekh-e-Karafs (Apium graveolans), Qaranful (Caryophyllus aromaticum), Fifile Siyah (Piper nigrum), Aaqar qarha(Anacylus pyrethrum), Zafran (Crocus sativus), Mastagi (Pistacia lentiscus), Ood Hindi (Agar agar), Bisbasa (Myristica fragrans), Asl-us-Soos (Glycerrhiza glabra), Qasab-uz-zareerah (Swertia chirata), Habb-ulQuilt (Dolichos biflorous), Post-e-Humiz (Ficus racemosa Linn), Qust (Sassuria lappa), Sumbul-ut-teeb (Nardostachis jatamansi), Asarun (Valariana walichii), Habbul Faham (Semicarpus anacardium), Aqrab (Scorpio maurus)), Habbul Ghar (Laurus nobilis), Saad Kofi (Cyperus rotundus), Bateekh (Cucumis melo), Mashkatra Maseeh (Mentha arvensis), Turbud (Operculina turpenthum), Juntiana (Gentiana kurru), Post Kibr (Capparis spinoso), Zaravand Madharj (Aristolochia rotunda), Afiyoon (Papaver somniferum), Farfiyoon (Euphorbia antiquorum ), Badam (Prunus amygdalus), Sarakhs (Dryopteris filixmas), Kishneez (Coriandrum sativum), Shaljam (Brassica rapa), Toot (Morus alba), Shooneez (Nigella sativa), Shahtara (Fumaria parviflora), Beekhe Turmis (Lupinus albus), Shitraj (Plumbago Zeylanica), Abhal (Juniperus communis), Honey (Apis indica), Sudab (Ruta graveolens), Halyoon (Aspragus officinalis), Pudina (Mentha spicata), Anar (Punica granatum), Jarjeer (Erusa sativa), Dammul Akhwain (Pterocarpus marsupium), Revand Chini (Rheum emodi), Habbe Katan (Linum usitatissimum), Baalchar (Nardostachys jatamans), Khas (Vetiveria zizanoides), Busd (Corallium rubrum), Kafe Darya (Sepia latimanus), Kakrundah (Blumea balsamfera), Hulba (Trigonella foenum-graecum), Mur (Commiphora myrrh), Sirka (Acetic acid), Arad Krisna (Pisum sativum), Mundi (Sphaeranthus indica), Marzanjosh (Origanum vulgare), Nakhood (Cicer aritenum), Kharnub (Phoenix dactylifera Linn), Ilaichi (Elletaria cardamomum), Kurras (Allium ascalonicum), Zaitoon (Oleum europium), Bikh Badrooj (Ocimum basilicum), Habbul Mahlab (Prunus mahaleb), Afsanteen (Artemissia absinthium), Hasha (Thymus linearis), Vaj (Acorus calomus), Sartan (Brachyura), Balsan (Balsamodendron opobalsamum), Akhrot (Juglans regia), Chilghoza (Pinus gerardiana), Aab Lohchan (Iron water), Rain Water, Badam (Prunus amygdalus), Pista (Pistacia vera), Sumaq (Rhus coriaria), Post Falsa (Grewia asiatica), Momiyai (Shilajeet), Izkhar (Cymbopogon citratus), Habbul Aas (Myrtus Communis), Duqu (Pencedanum grande), Khurfa (Portulaca oleracea), Kaknaj (Physali alkekengi), Tukhm Kahu (Lactuca sativa), Kateera (Sterculia urenus), Kutki (Picrorrhiza kurroa), Findaq (Corylus avellana), Khatmi (Althea officinalis), Hummaz (Rumex vesicaricus), Bathwa (Chenopodim album), Baadaward (Fagonia arabica), Baranjasif (Artemisia vulgaris), Gond Babul (Acacia Arabica), Jaephal (Myristica fragrance), Baloot (Quercus incana), Gulnar (Punica granatum), Tabasheer (Bambusa arundinacae), Jund Baidaster (Castoreum), Abnus (Diosphyus ebenum), Tukhm safar Jal (Cydonia oblonga), Gurhal (Hibiscus rosasinensis), Tukhm Sanmbhalu (Vitex negundu), Cholai (Amaranthus polygamus), Injeer (Ficus carica), Ood Salib (Paaeonia officinalis), Banafsaha (Viola odorata), Biskhapra (Trianthema portulaca), Bikh Sosan (Iris ensata), Tukhm Khubazi (Malva sylvestris), Luk Maghsul (Laccifer lacca), Ghariqoon (Agaricus alba), Maul Jubn (Cow's Churned Milk), Ajwain Khurasani (Hyoscymus niger), Parshiyonsha (Adiantum capillus), Sapistan (Cordia latifolia), Bisfaij (Polypodium vulgare), Ustakhuddus (Lavendula stoechas), Muql (Commiphora mukul), Jaosheer (Ferula galbaniflua), Sakbeenj (Ferula persica), Hanzal (Citrullus colocynthisis), Gule Ghafis (Gentiana olivieri), Chukandar (Beta vulgaris), Hajrul Yahood (Lapis judiacus), Babuna (Matricaria chamomilla) [15,17-24].

\section{Some Compound formulation}

Jawarish Zarooni Sada, Jawarish Zarooni Anbri Banuskha Kalan, Jawarish Jalinus, Majoon Flasifa, Majoon aqrab, Majoon Kundur, Majoon Masikul Baul, Majoon Sange Sarmahi, Majoon Zafran, Majoon Fanjanus, Sharbat Bazoori, Sharbat Annanas, Sharbat Aloobalu, Qurs 
Kushta Sadaf, Qurs Khusta Khabsul Hadeed, Qurs Kushta Qalai, Qurs Ziabetus, Qurs Tabasheer, Qurs Afawiya, Qurs Kaknaj, Qurs Kuharba, Roghan Akhrot, Roghan Badam, Roghan Balsan, Roghan Gul, Roghan Aqrab, Roghan Babuna, Dawaul Kurkum, Luboob Sagheer, Luboob Kabir, Kushta Aqeeque, Kushta Faulad, Kushta Hajrul Yahood, Kushta Baiza Murgh, Kushta Zamrad, Safoof Ziabetus, Safoof Hindi, Arque Badiyan, Halwae Maghz Sar Kunjushk, Habbe Mudir, Banadaqul Buzoor, Nuqu ul Buzoor, Amroosiya, Asanasiya Sagheer, Asanasiya Kabir [15,17,19,20,22-27].

\section{Scientific reports for mufrad and murakkab drugs mentioned above are as following}

Kabab Chini (Pipeber cubeba): Ahmad et al. reported that Kabab Chini powder exhibits nephroprotective effect in against Gentamicin induced nephrotoxicity at the dose of $800 \mathrm{mg} / \mathrm{kg}$ and $100 \mathrm{mg} / \mathrm{kg}$ in pretreated and post treated rat models [28].

Gule Surkh and Beekh Kasni (Rosa damascena and Cichorium intybus): Khaliq et al. reported that aqueous extract of Rosa damascena ( 250 and $500 \mathrm{mg} / \mathrm{kg}$ ), Cichorium intybus (250 and $500 \mathrm{mg} / \mathrm{kg}$ ) and their mixture (250 and $500 \mathrm{mg} / \mathrm{kg}$ ) revealed nephroprotective activity against gentamicin $(80 \mathrm{mg} / \mathrm{kg})$ induced nephrotoxicity in albino rabbits [29].

Jawarish Zarooni Sada (JZS): Gufran A et al, reported that compound drug JZS showed diuretic and nephroprotective effect against Gentamicine induced nephrotoxicity at the dose of $300 \mathrm{mg} / \mathrm{kg}$ body weight in albino rats [30].

\section{Conclusion}

In the light of Unani Medicine, Unani Attiba (Rhazi, Ibn Sina, Majoosi) described their classical text, various single and compound drugs for treating diseases of kidney on observation and clinical practice. When there was no such investigation available but on the basis of clinical experience diseases are diagnosed and treated on behalf of Usoole Ilaj. At present scenario most of the kidney patients are anaemic, during ancient time Unani physician also used rain water and iron water (Aab Ahan). The mechanism of the action of these might not be seen in present literature, but Usoole Ilaj from Unani medicine incorporates it in a systemic way. Zakaria Rhazi described various drugs for the treatment of amraze gurda, now a day most of them are claimed for the management of kidney disease and some of them are scientifically proved. Stepwise research is needed to explore hidden active chemical constituents and their mechanism of action. This type of review will be helpful for those who are scientist, physicians, researchers, interest in nephrology and patient care of kidney diseases to provide safe medicine in mankind.

\section{Acknowledgement}

I am grateful to all library staff for their valuable help and cooperation.

\section{References}

1. Porter GA, Bennett WM (1981) Nephrotoxic acute renal failure due to common drugs. Am J Physiol 241: F1-8.

2. Pydi R (2011) Nephroprotective medicinal plants- A review. Int J Univ Pharm Life Sci 1: 266- 281.

3. Hoitsma AJ, Wetzels JF, Koene RA (1991) Drug-induced nephrotoxicity Aetiology, clinical features and management. Drug Saf 6: 131-147.

4. http://www.bridgeoflifemm.org/

5. Jha V, Garcia-Garcia G, Iseki K, Li Z, Naicker S, et al. (2013) Chronic kidney disease: global dimension and perspectives. Lancet 382: 260-272.
6. Jha V (2013) Current status of end-stage renal disease care in India and Pakistan. Kidney International Supplements 3:157-160.

7. Begum NA, Dewan ZF, Nahar N, Mamun MIR (2006) Effect of n-Hexane extract of Nigella sativa on gentamicin induced nephrotoxicity in rats. Bangladesh $J$ Pharmacol 1: 16-20.

8. White SL, Chadban SJ, Jan S, Chapman JR, Cass A (2008) How can we achieve global equity in provision of renal replacement therapy? Bull World Health Organ 86: 229-237.

9. Ramya S, Rajasekaran C, Sivaperumal R, Krishnan A, Jayakumararaj R (2008) Ethnomedicinal Perspectives of Botanicals used by Malayali Tribes in Vatta Hills of Dharmapuri (TN), India. Ethnobotanical Leaflets 12:1054-1060.

10. Kumar A, Kumari SN, D'souza P, Bhargavan D (2013) Evaluation of Renal Protective Activity of Adhatoda Zeylanica (Medic) Leaves Extract in Wistar Rats. NUJHS 3: 45-47.

11. Bharti D, Raghunath T, Manoj Kumar Z, Namrata V (2012) Nephroprotective Plants: A Review. Int J Pharm Pharm 4: 8-16.

12. Meena MK, Kushwah HK, Manjusha rajagopala, Ravishankar B (2009) An experimental evaluation on nephroprotective activity of Nagaradi kashaya. AYU 30: 55-61.

13. Peesa JP (2013) Nephroprotective Potential of Herbal Medicines: A Review. Asian J Pharm Tech 3: 15-118.

14. Lakshmi MS, Reddy UKT, Rani SKS (2012) A Review on Medicinal Plants for Nephroprotective Activity. Asian J Pharm Clin Res 5: 8-14.

15. Rhazi Z (2002) Kitab Al-Hawi. Central Council for Research in Unani Medicine. Ministry of Health \& Family Welfare, Govt. of India, New Delhi.

16. Kabiruddin A (2006) Kulliyate Qanun. Eajaz Publication New Delhi.

17. Zohar I, Kitab Al Taiseer. Central Council for Research in Unani Medicine Ministry of Health \& Family Welfare, Govt. of India, New Delhi.

18. Alam MA, Ahmed S, Husain S, Bano H, Ahmed Z, et al. (2013) Kabab Chin (Piper cubeba) \& Its Healing Corollary in Unani Medicine: An Overview. Am J Pharm Health Res 1: 1-9

19. Baghdadi IH (2004) Kitab Al Mukhtarat Fil Tib. Central Council for Research in Unani Medicine. Ministry of Health \& Family Welfare, Govt. of India, New Delhi.

20. Jurjani AH (2010) Zakhira Kharzam Shahi. Idara Kitab Us Shifa New Delhi.

21. Kabiruddin M. Bayaze Kabir. Hikmat Book Depot Hyderabad (Deccan) India.

22. Anonymous (2006) National Formulary of Unani Medicine. Dept of AYUSH, Ministry of Health \& Family Welfare, Govt. Of India, New Delhi.

23. Majoosi AIA (2010) Kamil Us Sana. Idara Kitab Us Shifa New Delhi.

24. Sina I (2010) Alqanoon. Idara Kitab Us Shifa New Delhi.

25. Khan A (1983) Hazique. Madeena Publishing Company Kranchi.

26. Arzani A. Tibbe Akbar. Faisal Publication Deoband.

27. Khan MA (2011) Akseer-e-Azam. Idara Kitab Us Shifa New Delhi.

28. Ahmad QZ, Jahan N, Ahmad G; Tajuddin (2012) Nephroprotective effect of Kabab chini (Piper cubeba) in gentamycin-induced nephrotoxicity. Saudi J Kidney Dis Transpl 23: 773-781.

29. Khaliq T, Mumtaz F, Rahman Z, Javed I, Iftikha A (2013) Nephroprotective Potentia of Rosa damascena Mill Flowers, Cichorium intybus Linn Roots and Their Mixtures on Gentamicin-Induced Toxicity in Albino Rabbits. Pak Vet J 35: 43-47.

30. Afzal M, Khan NA, Ghufran A, Iqbal A, Inamuddin M (2004) Diuretic and nephroprotective effect of Jawarish Zarooni Sada--a polyherbal unan formulation. J Ethnopharmacol 91: 219-223. 